\title{
Branch Configuration Impacts on Production, Fruit Quality, and Leaf Minerals of 'Aztec Fuji' Apple Trees in an Upright Single Row High-Density Orchard System Over Five Years
}

\author{
Esmaeil Fallahi ${ }^{1}$, Bahar Fallahi ${ }^{1} \&$ Shahla Mahdavi ${ }^{1}$ \\ ${ }^{1}$ Parma Research and Extension Center, University of Idaho, Parma, Idaho, USA \\ Correspondence: Esmaeil Fallahi, Parma Research and Extension Center, University of Idaho, 29603 U of I Lane, \\ Parma, Idaho 83660, USA. Tel: 208-880-8088. E-mail: efallahi@uidaho.edu
}

Received: January 13, 2020

Accepted: February 15, 2020

Online Published: March 15, 2020

doi:10.5539/jas.v12n4p53

URL: https://doi.org/10.5539/jas.v12n4p53

\begin{abstract}
Tree architectures play a critical role in the productivity of high-density orchards, but limited information is available in this subject. We studied effects of three branch configurations on tree growth, yield components, fruit quality and leaf mineral nutrients in 'Aztec Fuji' apple (Malus domestica Bork.) in a single row upright high-density system under southwest Idaho, USA conditions over 2012-2016. This study revealed that trees trained into a Tall Spindle (TS) had larger trunk cross sectional area (TCSA) than those with an Overlapped Arm (OA) system. Trees trained into a TS had higher number of fruit and yield per tree, three years after planting in 2012, than those with a Tipping Arm (TA) or OA system. However, in 2013, trees with a TA system had higher yield than those with a TS or OA configuration due to trees' biennial bearing habit and higher spur formation in trees with a TA system. Trees receiving a TA training had lower biennial bearing index between all consecutive years. Trees with an OA training had smaller fruit than those with either a TA or TS training in all years between 2012-2016. Training systems did not have any effect on fruit color, soluble solids concentration, or starch degradation pattern at harvest. However, fruit from trees with an OA training had higher firmness and lower water core than those from trees with a TS or TA training. Leaves from trees receiving a TA training had greater leaf area, fresh weight, and potassium $(\mathrm{K})$ and magnesium $(\mathrm{Mn})$ concentrations than those with other trainings. Leaves from trees receiving an OA training had higher leaf iron $(\mathrm{Fe})$, zinc $(\mathrm{Zn})$, and copper $(\mathrm{Cu})$ than those with a TS training. In this study, we concluded that training trees into a TA configuration rather than an OA system is recommended if the management and operation of apple production mandate the use of an "upright wall" structure to facilitate mechanical harvesting.
\end{abstract}

Keywords: branch training, tree architecture, quality attributes

\section{Introduction}

Modern apple (Malus domestica Borkh) orchard systems, using size-controlling rootstocks, can result in production of high quality fruit (Autio, Hayden, Micke, \& Brown, 1996; Chun, Fallahi, Colt, Shafii, \& Tripepi, 2001; Fallahi, Colt, \& Fallahi, 2001; Fallahi, Chun, Neilsen, \& Colt, 2001; Fallahi, Fallahi, Shafii, \& Morales, 2007; Fallahi, Ratnaprabha, Tripepi, Shafii, \& Fallahi, 2007; Hoying, 2012). In these systems, higher crop per unit of land can be produced on highly efficient rootstocks, smaller trees, and new training systems (Hampson, Harvey, Quamme, \& Brownlee, 2002). Establishing a highly efficient orchard system with an appropriate rootstock and training system can also cause precocity, enables better spray coverage and facilitates better light penetration through the tree canopy (Dallabetta, Costa, Pasqualini, Noferini, \& Costa, 2014; Ozkan et al., 2012; Gandev et al., 2016; Kappel \& Quamme, 1993). The success in modern orchard management greatly depends on proper application of rootstock, branch and tree training system, and tree spacing (Wertheim, de Jager, \& Duyzens, 1986). Also, due to the challenges in labour availability, the ability of using mechanical equipment for automated cultural practices must be in the forefront of priorities in any modern orchard (He \& Schupp, 2018).

The use of Tall Spindle (TS) trees in high density orchards has become popular in the recent years, mainly because trees will produce in the second and third year after planting (Robinson, Hoying, \& Reginato, 2006). However, since TS is a relatively new technique, comparing performance of apple trees with this system and those with other training systems has become the focus of pomologists in the recent years (Fallahi, Kiester, 
Fallahi, \& Mahdavi, 2018; Clements, 2011). Clements (2011) studied the performance of 'Honeycrisp' and 'McIntosh' apples on Bud 9, M.26, and MM.106 rootstocks with a central leader (CL), vertical axis (VA), or TS tree architecture systems. In both cultivars, trees on Bud 9 had the highest year cumulative yield over 2008-2010 (during $3^{\text {rd }}$ through $5^{\text {th }}$ leaf), followed by those on M.26 and MM.106 rootstocks. In that study, trees with TS had the highest production per hectare, followed by those with VA and CL. In Idaho, training 'Fuji' apples on Bud 9 rootstock with a TS system resulted in more regular cropping than those on Nic 9 with a CL system (Fallahi, Kiester, Fallahi, \& Mahdavi, 2018).

Girdling or scoring for induction of branches in the desired area on the tree trunk and improvement of fruit has been practiced in several fruit crops including avocado (Persea americana) (Davie, Stassen, Van der Walt, \& Snijder, 1995), stone fruit (Agusti, Andreu, Juan, Almela, \& Zacarias, 1998; Day \& DeJong, 1990), pear trees (Pyrus communis) (Raffo et al., 2011), grapes (Vitis vinifera) (Reynolds \& de Savigny, 2004; Fallahi, Tehranifar, \& Gharaghani, 2017) and apple (Schechter, Proctor, \& Elfving, 1994; Fallahi, et al., 2018). However, bark girdling may impair tree and vine health if callusing is slow or inadequate (Fallahi, Kiester, Fallahi, \& Mahdavi, 2018; Fernandez-Escobar, Martin, Lopez-Rivares, \& Paz Suarez, 1987).

Limited information exists on the impact of branch manipulation on yields and fruit quality attributes of apples in high-density orchards. Therefore, the objective of this experiment was to study the effect of three branch configurations on tree growth, yield, fruit quality attributes and leaf mineral concentrations of 'Aztec Fuji' apple in a single row upright high-density system over five consecutive years between 2012 and 2016.

\section{Materials and Methods}

\subsection{Orchard Establishment and General Cultural Practices}

The experimental orchard was established at the Parma Research and Extension Center, University of Idaho, Parma, Idaho, USA in the spring and early-summer 2010. The experimental site was located at $43.7853^{\circ} \mathrm{N}$, $116.9422^{\circ} \mathrm{W}$, and had a semi-arid climate with an annual precipitation of approx. $297 \mathrm{~mm}$ on a sandy loam soil of approx. $\mathrm{pH}$ 7.3. In general, pest and diseases control practices were like those recommended for commercial orchards in the Pacific Northwest (Washington State University, 2020). Crested wheatgrass (Agropyron cristatum (L.) Gaertn.), a drought-tolerant grass, was planted as the orchard floor cover in all treatments. The materials and methods for irrigation system, mineral nutrients, bloom and post-bloom chemical applications and hand-thinning were similar to those previously described by Fallahi, Fallahi, Kiester, and Mahdavi (2018) and Fallahi, Mahdavi, Kaiser, \& Fallahi (2019). Trees were irrigated, using a drip system, twice a week, using $100 \%$ apple crop evapotranspiration (ETc) (Proebsting, 1994), but adjusted for the ground shading area (GS), as described by Allen, Pereira, Raes \& Smith (1998) and Fallahi, Fallahi, \& Shafii (2013).

\subsection{Tree Architecture or Training Treatments}

'Aztec Fuji' trees on Budagovsky 9 (Bud 9) rootstock (C \& O Nursery, Wenatchee, WA) were planted at $0.91 \times$ $3.66 \mathrm{~m}$ spacing in upright single rows with a north-south orientation. 'Snow Drift' crab apple (Malus $\times$ 'Snowdrift') on M.26 EMLA rootstock (C \& O Nursery, Wenatchee, WA) was planted between every 10 'Aztec Fuji' trees in each row as a pollinizer. One pressure-treated pole, with $15 \mathrm{~cm}$ diameter and $4.9 \mathrm{~m}$ length, was installed at every $7.31-\mathrm{m}$ spacing (between every 8 trees), with about $90 \mathrm{~cm}$ of the pole buried in the ground and $4 \mathrm{~m}$ above the ground. Seven rows of $4.96-\mathrm{mm}^{2}$ gauge galvanized wires were installed on the poles. The first wire was installed at $61 \mathrm{~cm}$ above the ground and the other 6 wires were installed $45 \mathrm{~cm}$ apart from each other in such a way that the last wire was installed at $3.31 \mathrm{~m}$ above the ground level. Branches were trained (configured) into one of the following three systems: 1) Tall Spindle (TS): In trees with a Tall Spindle training, only 14-18 "feathered small branches", equally spaced around the central leader of each tree, were remained and tied to the trunk at 110-degree angles from vertical, using cotton ties. In this technique, tree leaders were not removed, or were very minimally tipped (about $3 \mathrm{~cm}$ from the top) to eliminated meristems that were damaged during shipment. Tree leaders were maintained at approx. $3.75 \mathrm{~m}$ in height. No permanent scaffolds or branches were left on the main trunk and side branches were bevel cut back to $15-\mathrm{cm}$ stubs when their diameters were thicker than $1 / 2$ to $2 / 3$ of the diameter of the main leader, to generate new fruiting shoots. 2) Overlapped Arm (OA): The basic structure of this training was similar to the TS system. However, in the OA system, only seven pairs of bilateral cordon arms were chosen or created in the north-south orientation (along the row) at $90^{\circ}$ in relation to and at about $45 \mathrm{~cm}$ apart along the main trunk and these arms were tied to the wires in a horizontal orientation during late dormant throughout the entire growing season. Other branches or feathers were eliminated. Thus, all arms of trees with an OA system were on the same plane. In this system, the tip of each arm remained uncut until it reached the main trunk of the next tree. Thus, arms of the two adjacent trees would "overlap" each other in an OA system. If an arm did not exist in the exact desired place on the trunk, a 3-4-cm cut (scoring) was made through the bark 
cambium layer at about 6-7 $\mathrm{mm}$ above an outward going bud in that place, using a sharp scoring knife. In this system, risers (shoot suckers) that grew from each arm were cut short to about $15 \mathrm{~cm}$, preferably down to an outward growing shoot, at any time during the growing season to create spur structure, similar to the system described by Goodwin (2016); 3) Tipped Arm system (TA): Trees with a TA training system were identical to those with an OA system except that the tip of each arm in the TA was cut and maintained at half-way between the two adjacent trees, at $45 \mathrm{~cm}$ distance from the main trunk of each tree.

\subsection{Tree Growth, Yield and Quality Attributes}

To determine tree growth, tree trunk diameter was measured from $30 \mathrm{~cm}$ above the bud union (about $35 \mathrm{~cm}$ from the soil level), using a digital caliper, in early November of each year in 2012-2016, and trunk cross sectional area (TCSA) was calculated. Yield per tree was recorded at harvest time, and twenty fruits were randomly sampled from each tree for measuring quality attributes on October 17-20 each year. For quality attribute evaluation at harvest, fruits were weighed, and fruit color was visually ranked on a scale of 1 to 5 , with $1=20 \%$ red, progressively to $5=100 \%$ red. Soluble solids concentration (SSC) was measured by a temperature-compensated refractometer (Atago N1, Tokyo, Japan). Fruit firmness was measured on three peeled sides of each fruit with a Fruit Texture Analyzer (Guss, Strand, Western Cape, South Africa). This texture tester measured the force needed to puncture a $7.9 \mathrm{~mm}$-deep hole on each of the three peeled sides of the fruit, using an 11-mm tip. Starch degradation pattern (SDP) of equatorial slices of each fruit was recorded by comparison with the SDP standard chart developed for 'Fuji' apples (Bartram et al., 1993). In that chart, SDP is scaled from 1 to 6 ( 1 = least fruit SDP, progressively to $6=$ most SDP or starch hydrolysis). Percentage of fruit water core at harvest was calculated by counting the total number of fruits with each of these incidences, divided by the total number of fruits in the sub-sample and multiplied by 100 .

\subsection{Leaf Weight and Mineral Nutrient Measurements}

Thirty leaves per tree were sampled at random from the middle of the current-season shoots in mid-August each year. These leaves were put in a cooler and taken to the University of Idaho Pomology and Viticulture Laboratories where their fresh weights were measured. Leaf preparation and digestion for mineral analyses were similar to those described in earlier reports (Chaplin \& Dixon, 1974; Fallahi, Fallahi, Kiester, \& Mahdavi, 2018).

\subsection{Experimental Designs and Statistics}

The experimental design in each year was a randomized complete block with three branch configurations (trainings), each with four 2-tree blocks (total of eight trees per branch configuration treatment). Interaction between years for each parameter was also calculated. The assumption of normal data distribution was checked by computing univariate analyses for all tree responses in this study. Analyses of variance was conducted using SAS (SAS Institute, Cary, NC, USA), with GLM and means were compared by least significant difference (LSD) at $\mathrm{P} \leq 0.05$.

\section{Results and Discussion}

\subsection{Interaction}

Other than the cases in branch configuration systems for yield components (yield per tree, yield efficiency, crop efficiency, and number of fruits per tree) between years 2012 and 2013, no significant interaction was observed between branch configuration-year for any measurements in this study. Thus, only effects of direct tree architectures (branch configurations) are reported in Tables 1-5.

Table 1. Influence of branch configuration (tree architecture) on tree growth (trunk cross sectional area) and the number of fruits per tree in an upright single-row planting system of 'Aztec Fuji' apple on Bud.9 rootstock over 2012-2016

\begin{tabular}{|c|c|c|c|c|c|c|c|c|c|c|}
\hline \multirow{2}{*}{ Branch configuration } & \multicolumn{5}{|c|}{ Trunk cross sectional area $\left(\mathrm{cm}^{2}\right)$} & \multicolumn{5}{|c|}{ Fruit number per tree } \\
\hline & $2012^{z}$ & 2013 & 2014 & 2015 & 2016 & 2012 & 2013 & 2014 & 2015 & 2016 \\
\hline Overlapped Arm & $8.2^{\mathrm{b}}$ & $10.2^{\mathrm{b}}$ & $10.6^{\mathrm{b}}$ & $12.7^{\mathrm{b}}$ & $14.7^{\mathrm{b}}$ & $35^{\mathrm{b}}$ & $15^{\mathrm{b}}$ & $63^{\mathrm{a}}$ & $67^{\mathrm{a}}$ & $143^{\mathrm{a}}$ \\
\hline Tipped Arm & $9.3^{\mathrm{ab}}$ & $11.8^{\mathrm{ab}}$ & $12.9^{\mathrm{ab}}$ & $14.8^{\mathrm{ab}}$ & $17.5^{\mathrm{ab}}$ & $18^{\mathrm{c}}$ & $33^{\mathrm{a}}$ & $66^{\mathrm{a}}$ & $102^{\mathrm{a}}$ & $119^{\mathrm{a}}$ \\
\hline Tall Spindle & $10.6^{\mathrm{a}}$ & $13.7^{\mathrm{a}}$ & $14.6^{\mathrm{a}}$ & $17.6^{\mathrm{a}}$ & $20.2^{\mathrm{a}}$ & $49^{\mathrm{a}}$ & $13^{\mathrm{b}}$ & $80^{\mathrm{a}}$ & $74^{\mathrm{a}}$ & $164^{\mathrm{a}}$ \\
\hline Significance ${ }^{\mathrm{z}}$ & $*$ & $*$ & $*$ & $*$ & $*$ & $* *$ & $*$ & ns & ns & ns \\
\hline
\end{tabular}

Note. ${ }^{\mathrm{z}}$ Mean and Significance denotations: Mean values within each column followed by different letters are significant at $5 \%(*), 1 \%(* *)$ and those followed by the same letters are not different at $5 \%$ (ns), using least significant difference test. 
Table 2. Influence of branch configuration (tree architecture) on yield per tree and yield efficiency in an upright single-row planting system of 'Aztec Fuji' apple on Bud.9 rootstock between 2012-2016

\begin{tabular}{|c|c|c|c|c|c|c|c|c|c|c|c|c|}
\hline \multirow[b]{2}{*}{ Branch configuration } & \multicolumn{6}{|c|}{ Yield (kg/tree) } & \multicolumn{6}{|c|}{ Yield efficiency $\left(\mathrm{kg}\right.$ yield $/ \mathrm{cm}^{2}$ TCSA) ${ }^{\mathrm{z}}$} \\
\hline & $2012^{y}$ & 2013 & 2014 & 2015 & 2016 & $\begin{array}{l}\text { Cum. } \\
\text { Yield }\end{array}$ & 2012 & 2013 & 2014 & 2015 & 2016 & $\begin{array}{l}\text { Cum. } \\
\text { 2012-16 }\end{array}$ \\
\hline Overlapped Arm & $6.46^{\mathrm{b}}$ & $2.73^{\mathrm{b}}$ & $13.53^{\mathrm{b}}$ & $13.33^{\mathrm{a}}$ & $27.33^{\mathrm{ab}}$ & $63.45^{\mathrm{a}}$ & $0.80^{\mathrm{a}}$ & $0.27^{\mathrm{b}}$ & $1.26^{\mathrm{a}}$ & $1.05^{\mathrm{ab}}$ & $1.86^{\mathrm{a}}$ & $2.30^{\mathrm{a}}$ \\
\hline Tipped Arm & $4.66^{\mathrm{b}}$ & $7.30^{\mathrm{a}}$ & $15.56^{\mathrm{ab}}$ & $21.10^{\mathrm{a}}$ & $24.54^{\mathrm{b}}$ & $73.15^{\mathrm{a}}$ & $0.52^{\mathrm{b}}$ & $0.62^{\mathrm{a}}$ & $1.22^{\mathrm{a}}$ & $1.42^{\mathrm{a}}$ & $1.39^{\mathrm{b}}$ & $4.21^{\mathrm{a}}$ \\
\hline Tall Spindle & $10.46^{\mathrm{a}}$ & $3.15^{\mathrm{b}}$ & $20.10^{\mathrm{a}}$ & $17.39^{\mathrm{a}}$ & $37.30^{\mathrm{a}}$ & $88.39^{\mathrm{a}}$ & $1.00^{\mathrm{a}}$ & $0.21^{\mathrm{b}}$ & $1.38^{\mathrm{a}}$ & $0.95^{\mathrm{b}}$ & $1.89^{\mathrm{a}}$ & $4.38^{\mathrm{a}}$ \\
\hline Significance ${ }^{\mathrm{z}}$ & $* *$ & $*$ & $*$ & ns & $*$ & ns & $* *$ & $*$ & ns & $*$ & $*$ & $\mathrm{~ns}$ \\
\hline
\end{tabular}

Note. ${ }^{z}$ TCSA $=$ trunk cross sectional area.

${ }^{y}$ Mean and Significance denotations: Mean values within each column followed by different letters are significant at $5 \%(*), 1 \%(* *)$ and those followed by the same letters are not different at $5 \%(\mathrm{~ns})$, using least significant difference test.

Table 3. Influence of branch configuration (tree architecture) on crop efficiency and biennial bearing index (BBI) in an upright single-row planting system of 'Aztec Fuji' apple on Bud.9 rootstock

\begin{tabular}{|c|c|c|c|c|c|c|c|c|c|c|}
\hline \multirow{2}{*}{ Branch configuration } & \multicolumn{5}{|c|}{ Crop efficiency (fruit number/TCSA) ${ }^{z}$} & \multicolumn{5}{|c|}{ Biennial bearing index between two consecutive years } \\
\hline & $2012^{y}$ & 2013 & 2014 & 2015 & 2016 & $2012-13$ & 2013-14 & $2014-15$ & $2015-16$ & Avg. all years \\
\hline Overlapped Arm & $4.30^{\mathrm{a}}$ & $1.42^{\mathrm{ab}}$ & $5.97^{\mathrm{a}}$ & $5.28^{\mathrm{ab}}$ & $9.78^{\mathrm{a}}$ & $0.68^{\mathrm{a}}$ & $0.74^{\mathrm{a}}$ & $0.16^{\mathrm{ab}}$ & $0.35^{\mathrm{a}}$ & $0.48^{\mathrm{a}}$ \\
\hline Tipped Arm & $2.02^{\mathrm{b}}$ & $2.86^{\mathrm{a}}$ & $5.28^{\mathrm{a}}$ & $6.99^{\mathrm{a}}$ & $6.92^{\mathrm{b}}$ & $0.33^{\mathrm{b}}$ & $0.37^{\mathrm{b}}$ & $0.07^{\mathrm{b}}$ & $0.23^{\mathrm{b}}$ & $0.25^{\mathrm{b}}$ \\
\hline Tall Spindle & $4.92^{\mathrm{a}}$ & $0.90^{\mathrm{b}}$ & $5.63^{\mathrm{a}}$ & $4.06^{\mathrm{b}}$ & $8.41^{\mathrm{ab}}$ & $0.63^{\mathrm{a}}$ & $0.78^{\mathrm{a}}$ & $0.24^{\mathrm{a}}$ & $0.42^{\mathrm{a}}$ & $0.52^{\mathrm{a}}$ \\
\hline Significance ${ }^{z}$ & $* *$ & $*$ & ns & $*$ & $*$ & $* *$ & $* *$ & $*$ & $*$ & $* *$ \\
\hline
\end{tabular}

Note. ${ }^{\mathrm{z}} \mathrm{TCSA}=$ trunk cross sectional area in $\mathrm{cm}^{2}$.

${ }^{y}$ Mean and Significance denotations: Mean values within each column followed by different letters are significant at $5 \%(*), 1 \%(* *)$ and those followed by the same letters are not different at $5 \%(\mathrm{~ns})$, using least significant difference test.

Table 4. Influence of branch configuration (tree architecture) on fruit weight and quality attributes at harvest in an upright single-row planting system of 'Aztec Fuji' apple on Bud.9 rootstock over 2012-2016

\begin{tabular}{|c|c|c|c|c|c|c|c|c|c|c|c|}
\hline \multirow[b]{2}{*}{ Branch configuration } & \multicolumn{6}{|c|}{ Average fruit weight (g) } & \multicolumn{5}{|c|}{ Fruit quality average values over 2012-2016 } \\
\hline & $2012^{z}$ & 2013 & 2014 & 2015 & 2016 & $2012-16$ & $\begin{array}{l}\text { Color } \\
(1-5)^{y}\end{array}$ & $\begin{array}{l}\text { SSC } \\
(\text { Brix\% })^{y}\end{array}$ & $\begin{array}{l}\text { Firmness } \\
(\mathrm{N})\end{array}$ & $\begin{array}{l}\text { SDP } \\
(1-6)^{y}\end{array}$ & $\begin{array}{l}\text { Watercore } \\
(\%)\end{array}$ \\
\hline Overlapped Arm & $191.5^{\mathrm{b}}$ & $186.4^{\mathrm{b}}$ & $212.0^{\mathrm{b}}$ & $202.5^{\mathrm{b}}$ & $193.1^{\mathrm{b}}$ & $197.1^{\mathrm{b}}$ & $4.38^{\mathrm{a}}$ & $15.8^{\mathrm{a}}$ & $81.4^{\mathrm{a}}$ & $4.07^{\mathrm{a}}$ & $11.5^{\mathrm{b}}$ \\
\hline Tipped Arm & $255.4^{\mathrm{a}}$ & $222.7^{\mathrm{a}}$ & $231.5^{\mathrm{a}}$ & $214.9^{\mathrm{a}}$ & $214.6^{\mathrm{a}}$ & $227.8^{\mathrm{a}}$ & $4.29^{\mathrm{a}}$ & $15.6^{\mathrm{a}}$ & $78.9^{\mathrm{b}}$ & $4.08^{\mathrm{a}}$ & $18.1^{\mathrm{a}}$ \\
\hline Tall Spindle & $212.4^{\mathrm{b}}$ & $221.5^{\mathrm{a}}$ & $248.2^{\mathrm{a}}$ & $233.1^{\mathrm{a}}$ & $228.5^{\mathrm{a}}$ & $228.7^{\mathrm{a}}$ & $4.33^{\mathrm{a}}$ & $15.6^{\mathrm{a}}$ & $78.3^{\mathrm{b}}$ & $4.29^{\mathrm{a}}$ & $22.7^{\mathrm{a}}$ \\
\hline Significance ${ }^{\mathrm{z}}$ & $* *$ & $*$ & $*$ & $*$ & $*$ & $*$ & ns & ns & $* *$ & $\mathrm{~ns}$ & $*$ \\
\hline
\end{tabular}

Note. ${ }^{\mathrm{z}}$ Mean and Significance denotations: Mean values within each column followed by different letters are significant at $5 \%(*), 1(* *)$ and those followed by the same letters are not different at $5 \%(\mathrm{~ns})$, using least significant difference test.

${ }^{\mathrm{y}}$ Fruit color rank: $1=$ least red color, 5 highest red color. $\mathrm{SSC}=$ soluble solids concentration. $\mathrm{SDP}=\mathrm{Starch}$ degradation pattern: $1=$ least starch degradation; $6=$ highest starch hydrolysis. 
Table 5. Influence of branch configuration (tree architecture) on leaf fresh and percent dry weight and mineral concentrations in an upright single-row planting system of 'Aztec Fuji' apple on Bud.9 rootstock over 2012-2016

\begin{tabular}{|c|c|c|c|c|c|c|c|c|c|c|c|c|c|c|c|}
\hline \multirow{2}{*}{$\begin{array}{l}\text { Branch } \\
\text { configuration }\end{array}$} & \multirow{2}{*}{$\begin{array}{l}\text { Avg. } \\
\text { leaf area } \\
\left(\mathrm{cm}^{2} / \text { leaf }\right)^{z}\end{array}$} & \multirow{2}{*}{$\begin{array}{l}\text { Avg. } \\
\text { fresh } \\
\text { weight } \\
\text { (g/leaf) }\end{array}$} & \multirow{2}{*}{$\begin{array}{l}\text { Avg. } \\
\text { dry } \\
\text { weight } \\
(\%)\end{array}$} & \multicolumn{6}{|c|}{ Leaf $N(\%$ dwt $)$} & \multicolumn{6}{|c|}{ Leaf minerals (average over 2012-2016) } \\
\hline & & & & 2012 & 2013 & 2014 & 2015 & 2016 & $\begin{array}{l}\text { Avg. } \\
2012-16\end{array}$ & $\begin{array}{l}\mathrm{K} \\
(\% \mathrm{dwt})\end{array}$ & $\begin{array}{l}\mathrm{Mg} \\
(\% \mathrm{dwt})\end{array}$ & $\begin{array}{l}\mathrm{Fe} \\
(\mathrm{ppm})\end{array}$ & $\begin{array}{l}\mathrm{Mn} \\
(\mathrm{ppm})\end{array}$ & $\begin{array}{l}\mathrm{Zn} \\
(\mathrm{ppm})\end{array}$ & $\begin{array}{l}\mathrm{Cu} \\
(\mathrm{ppm})\end{array}$ \\
\hline Overlapped Arm & $18.9 \mathrm{~b}$ & $0.27 b$ & $42.1 \mathrm{a}$ & $2.32 \mathrm{a}$ & $2.10 \mathrm{~b}$ & $2.39 \mathrm{a}$ & $2.30 \mathrm{a}$ & $2.49 \mathrm{ab}$ & $2.32 \mathrm{a}$ & $1.15 \mathrm{~b}$ & $0.32 b$ & $93.2 \mathrm{a}$ & $90.0 \mathrm{~b}$ & $39.9 \mathrm{a}$ & $7.8 \mathrm{a}$ \\
\hline Tipped Arm & $23.3 \mathrm{a}$ & $0.62 \mathrm{a}$ & $41.1 \mathrm{~b}$ & $2.18 \mathrm{~b}$ & $2.22 \mathrm{a}$ & $2.43 \mathrm{a}$ & $2.39 \mathrm{a}$ & $2.41 \mathrm{~b}$ & $2.33 \mathrm{a}$ & $1.30 \mathrm{a}$ & $0.36 \mathrm{a}$ & $90.0 \mathrm{~b}$ & $96.8 \mathrm{a}$ & $39.6 \mathrm{ab}$ & $7.8 \mathrm{a}$ \\
\hline Tall Spindle & $18.1 \mathrm{~b}$ & $0.21 b$ & $41.2 b$ & $2.27 \mathrm{a}$ & $2.10 \mathrm{~b}$ & $2.45 \mathrm{a}$ & $2.30 \mathrm{a}$ & $2.61 \mathrm{a}$ & $2.35 \mathrm{a}$ & $1.10 \mathrm{~b}$ & $0.34 \mathrm{ab}$ & $88.4 \mathrm{~b}$ & $86.0 \mathrm{~b}$ & $37.8 \mathrm{~b}$ & $7.1 \mathrm{~b}$ \\
\hline Significance ${ }^{\mathrm{z}}$ & $* *$ & $*$ & $* *$ & $* *$ & $* *$ & $\mathrm{~ns}$ & ns & $* *$ & ns & $* *$ & $*$ & $* *$ & $*$ & & $*$ \\
\hline
\end{tabular}

Note. ${ }^{\mathrm{z}}$ Mean and Significance denotations: Mean values within each column followed by different letters are significant at $5 \%(*), 1(* *)$ and those followed by the same letters are not different at $5 \%$ (ns), using least significant difference test.

\subsection{Tree Growth and Production Pattern}

Trees trained into a TS system had significantly greater TCSA than those with an OA training system every year in 2012-2016 (Table 1). Every tree with a TS branch configuration always had more than 18 side branches and thus greater foliage than those with either a TA or OA system, each of which had a maximum of 14 arms (7 rows of wire, each with 2 arms). Higher foliage in trees with a TS configuration might have resulted in a greater leaf/fruit ratio and thus more TCSA. A strong correlation between TCSA and canopy growth was first reported by Westwood and Roberts (1970). No significant TCSA difference was observed between trees with a TA and OA training system.

Branch growth, bud formation, and production patterns in trees with different ages, stages of growth, and branch configurations are shown in Figures 1-6. Spurs and fruits in trees with an OA and TA configurations were developed along wires in perfectly regular "window patterns" two to four years after planting and Figures 1, 2, and 4 clearly show the regular production after fourth year in 2014. However, these window patterns in OA and TA configurations became more irregular as trees were older, because spurs and fruits were produced farther from the main arms (from the wires) in the older trees (Figure 5). This observation suggests that the fruit production in the older trees with an OA or TA branch configurations would have remained closer to the main arms if we had pruned the risers and side spurs branches shorter than $15 \mathrm{~cm}$ (closer to the arms) every year. In trees receiving a TS branch configuration, the general shape (pattern) of canopies in trees at different ages and stages of growth (bloom time and harvest time) remained relatively unchanged (Figures 3 and 6).

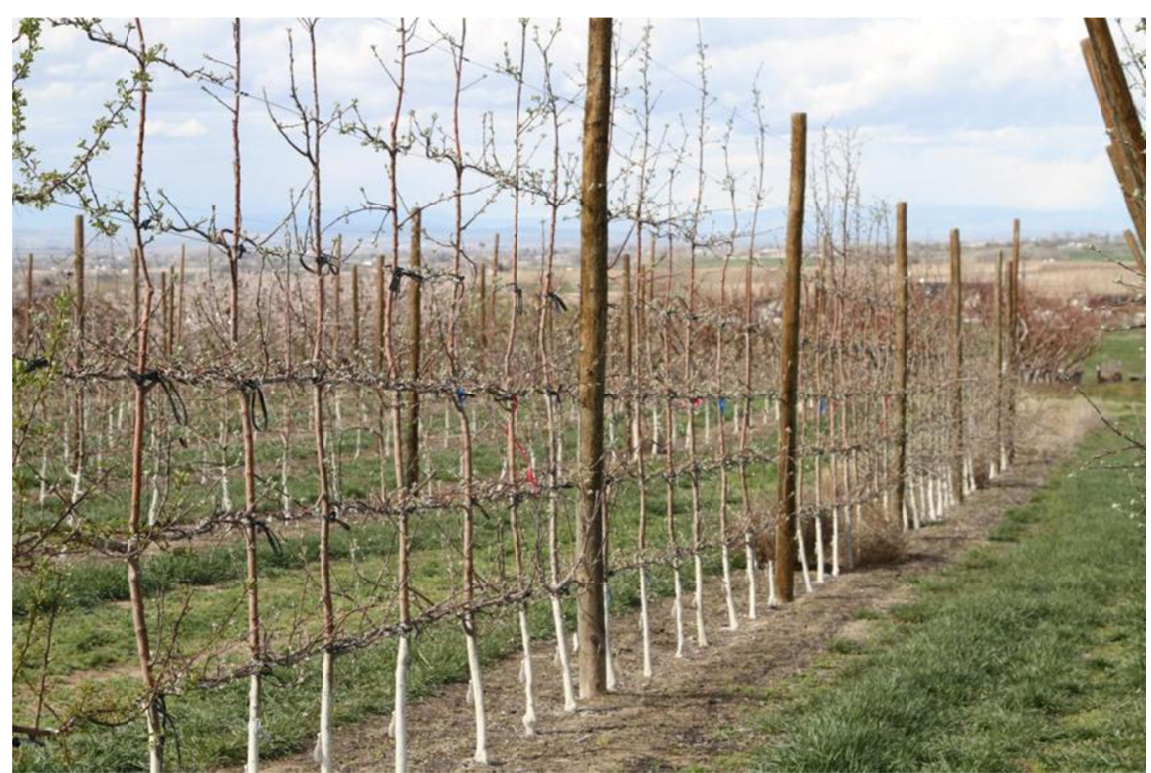

Figure 1. An upright single row planting with Overlapped Arm (OA) configuration on April 4, 2014 (four years after planting) 


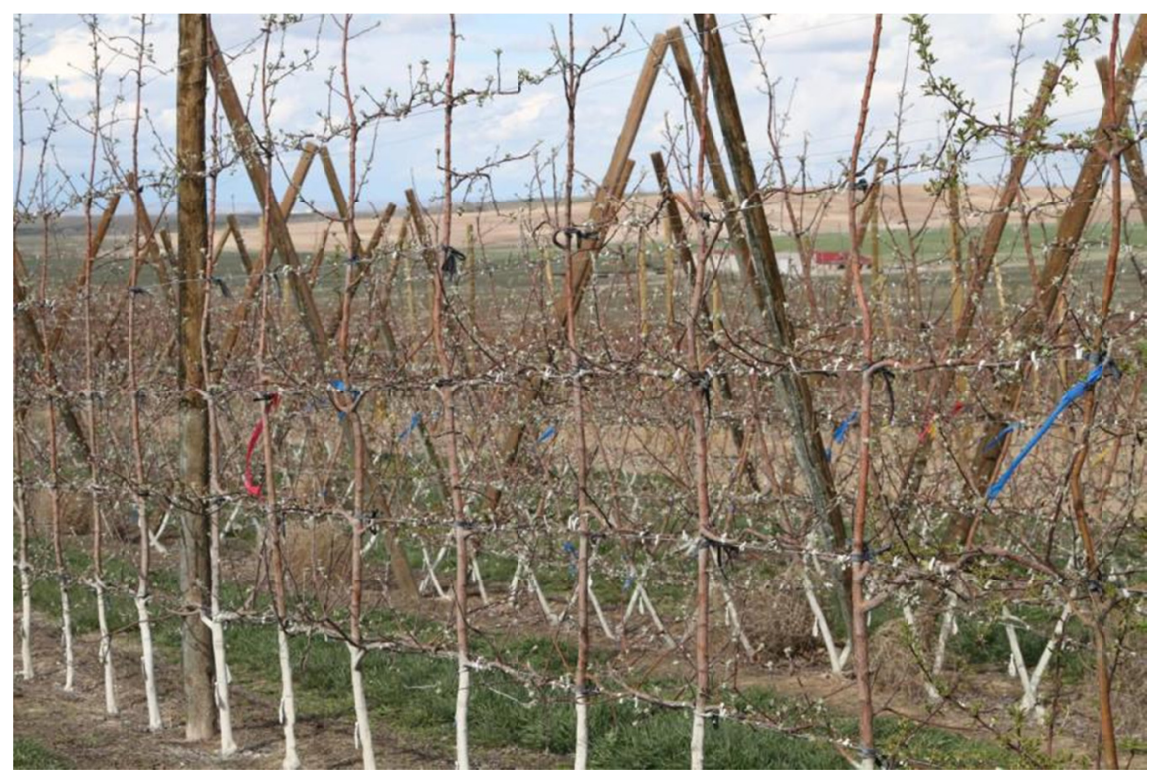

Figure 2. An upright single row planting with Tipped Arm (TA) configuration on April 4, 2014 (four years after planting)

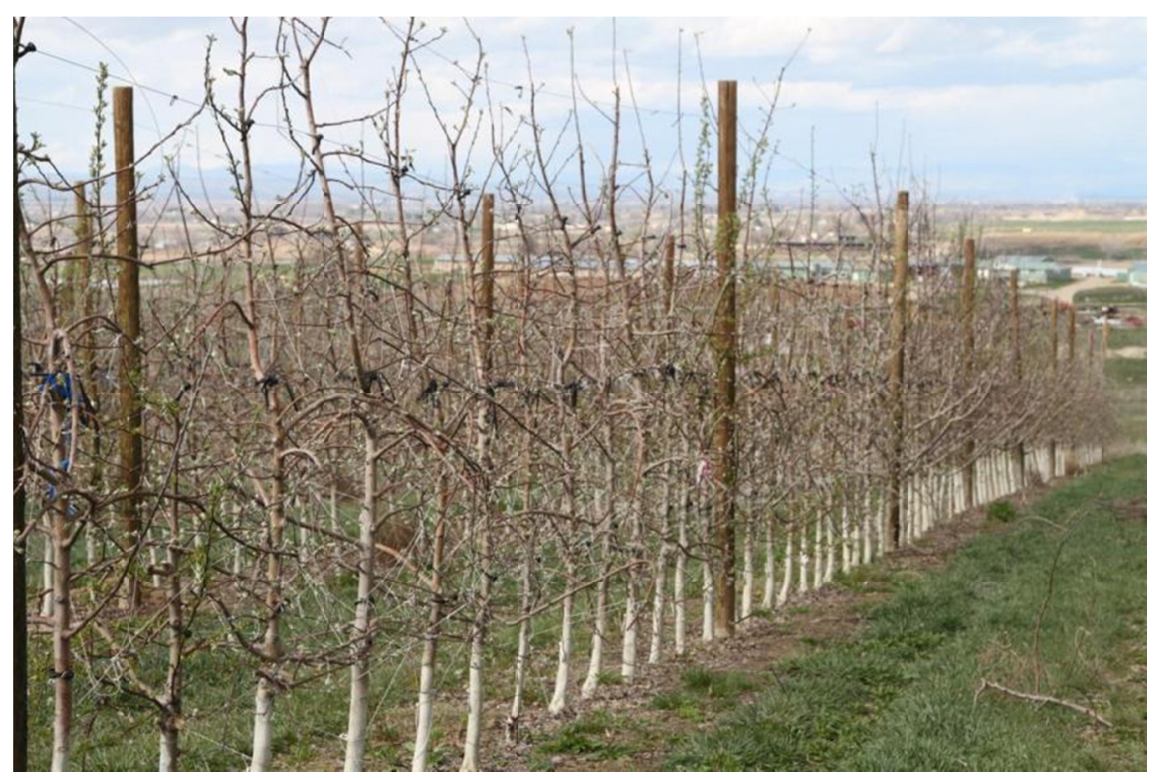

Figure 3. An upright single row planting with Tall Spindle (TS) configuration on April 4, 2014 (four years after planting) 


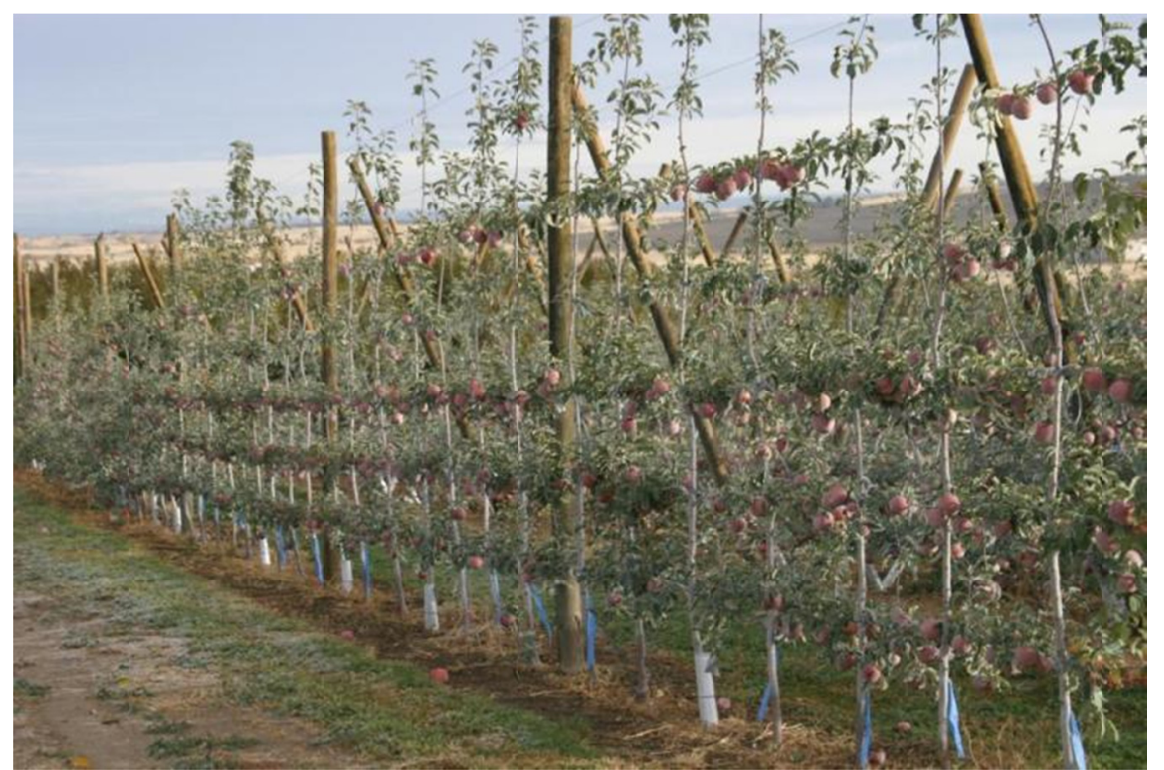

Figure 4. An upright single row planting with Tipped Arm (TA) and Overlapped Arm (OA) configuration in late September 2014

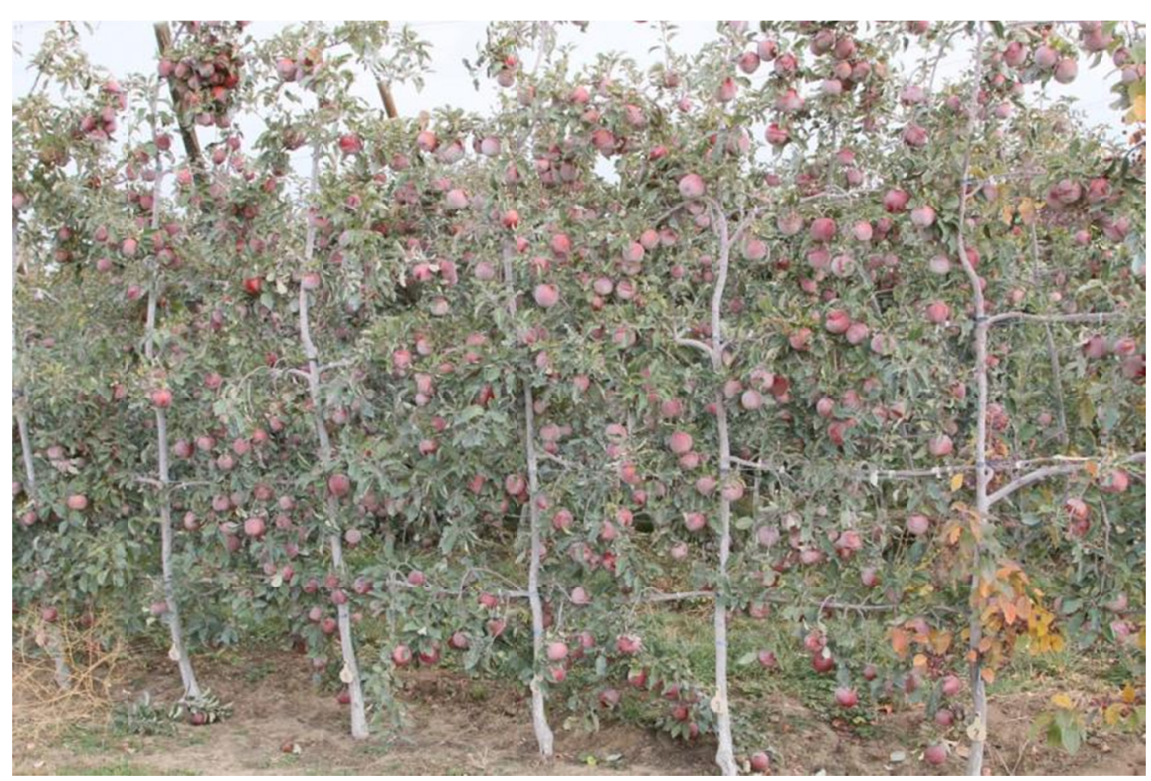

Figure 5. An upright single row planting with Tipped Arm configuration (TA) in late September, five years after planting 


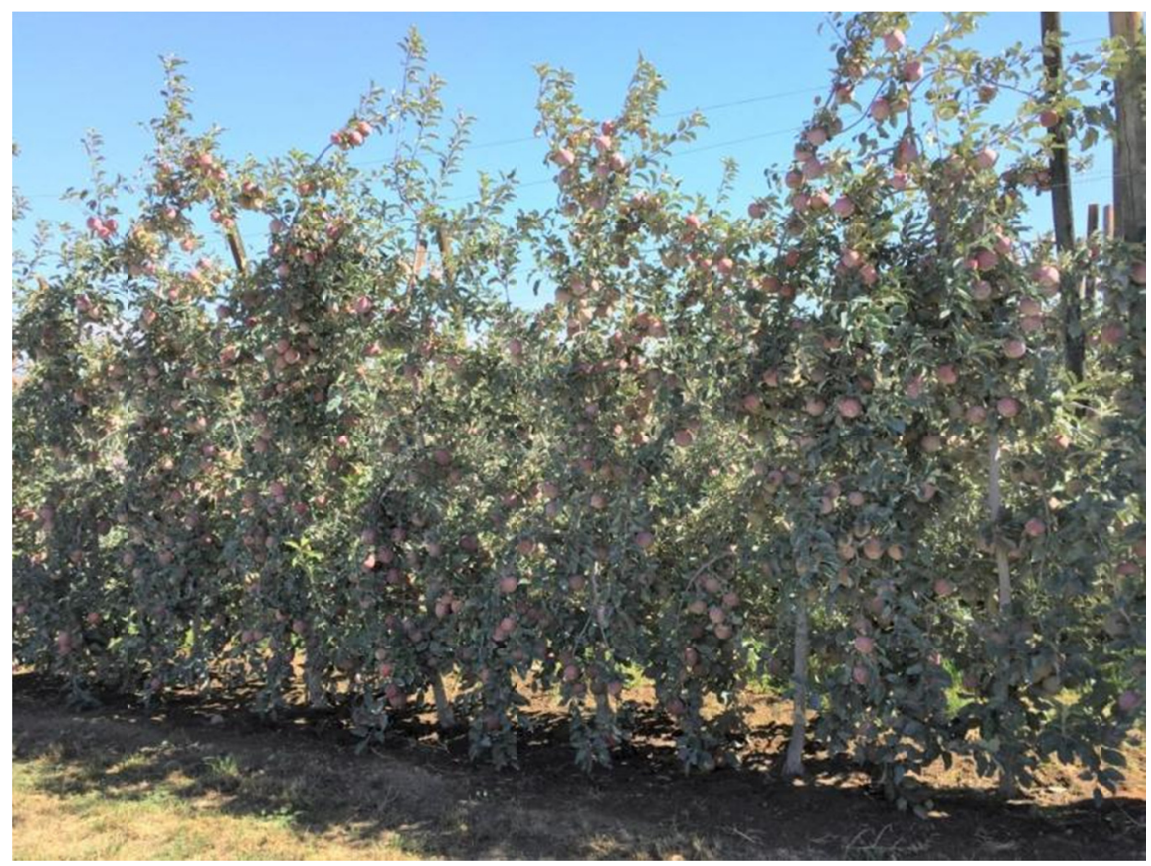

Figure 6. An upright single row planting with Tall Spindle branch configuration (TS) in late September five years after planting

\subsection{Fruit Number, Yield, Yield Efficiency, and Crop Efficiency}

Trees trained into a TS had significantly higher numbers of fruit in 2012 (Table 1) and tended to have higher yields per tree in 2012, 2014, and 2016 (Table 2) than those with a TA or OA system. This result agreed with a previous report where trees with a TS training had significantly higher yield than those with permanent lower scaffolds-central leader in one year (Fallahi, Kiester, Fallahi, \& Mahdavi, 2018). However, in 2013, this trend was reversed due to trees' biennial bearing habit and an increase in the spur formation, and thus trees with a TA had higher yield and fruit number per tree than those with a TS system (Tables 1 and 2). No significant differences existed in the number of fruits after 2013 (Table 1) or in the 5-year cumulative yield per tree among branch configuration treatments (Table 2). The effects of branch configuration treatments on yield efficiency (Table 2) and crop efficiency (Table 3) mostly mirrored those on the fruit number (Table 1) and yield per tree (Table 2).

\subsection{Biennial Bearing Index}

Trees receiving a TA configuration treatment had significantly lower biennial bearing index between all consecutive years. No significant differences existed in the BBI between trees with an OA and TS trainings (Table 3). Low BBI in trees with a TA system is an extremely positive yield attribute, as it assures a rather sustainable production every year. Consistency in production allows growers to have a much better control on marketing strategy of their apples.

\subsection{Fruit Weight and Quality Attributes}

Fruit from trees receiving an OA training had significantly smaller fruit than those receiving either a TA or TS branch training in all years between 2012-2016 (Table 4). Trees with an OA branch configuration had smaller TCSA (Table 1), and thus smaller tree foliage (Westwood and Roberts, 1970), leading to a lower leaf-to-fruit ratio and thus, smaller fruit size (Table 4). In 2012, trees receiving a TA training had significantly larger fruit because of their lower yields than those from trees with a TS branch configuration (Tables 2 and 4). However, no significant difference was observed in the fruit size between trees with TA and TS training systems after 2012 (Table 4).

Training systems did not have any significant effect on 5-year average values of fruit color, SSC, or SDP at harvest (Table 4). However, fruit from trees receiving an OA training had significantly higher firmness and lower water core than those from trees receiving a TS or TA branch configuration over five years. This could be because trees with an OA had smaller fruit (Table 4) and perhaps higher fruit Ca concentrations, as previously reported in 'Delicious' apple by Fallahi and Simons (1993). 


\subsection{Leaf Growth and Mineral Concentrations}

Leaves from trees receiving a TA branch configuration system had significantly greater leaf area, fresh weight, $\mathrm{K}$ and Mn concentrations than those with other branch training systems (Table 5), perhaps because leaves from trees with a TA branch configuration had higher rate of photosynthesis and this area deserves further study. Maintaining higher annual leaf $\mathrm{K}$ levels in a high-density system is extremely critical. For example, in a side-test, soil $\mathrm{K}$ levels in our experimental site at the time of planting was well in the sufficiency range. However, scion leaf $\mathrm{K}$ declined with every year of fruit production when supplementary $\mathrm{K}$ was not applied (data not shown). The lower BBI in trees receiving a TA configuration could be in part due to their higher leaf $\mathrm{K}$ concentrations and this area deserves further study.

Averaging over five years revealed that leaf $\mathrm{K}$ concentration in trees receiving a TA branch training system was in the sufficiency range while those in trees with OA and TS systems were bordering deficiency ranges based on Westwood (1978) and Mills and Jones (1996). Thus, it is extremely important to consider several genetic, environmental and cultural practices factors when interpreting results of leaf mineral analyses and before recommending any nutrients remedies. As an example, one may interpret and recommend the same rate of $\mathrm{K}$ fertilizer application in all apple trees with different training systems, without regard to their branch configuration, and resulting in under application of $\mathrm{K}$ in some and over application of $\mathrm{K}$ in other trees. In an earlier report in 'Gala apples', leaf $\mathrm{K}$ had a positive correlation with the rootstock vigor (Fallahi, Arzani, \& Fallahi, 2013). In our present study, however, TCSA of trees with different branch configurations were not strongly correlated to their scion leaf $\mathrm{K}$ because tree vigor differences were created by manipulating branch architectures system rather than rootstock.

Leaves from trees receiving an OA branch configuration had significantly higher leaf $\mathrm{Fe}, \mathrm{Zn}$, and $\mathrm{Cu}$ than those with a TS system (Table 5), perhaps because leaves of trees with an OA branch configuration have thinner cuticle and thus absorb more of certain micronutrient sprays. This area also deserves further study.

\section{Conclusions}

This study revealed that trees trained into a TS system had larger TCSA than those with an OA branching system. Trees receiving a TA training had lower biennial bearing index between all consecutive years. Fruit from trees with an OA training had smaller fruit than those with either a TA or TS training in all years. Training systems did not have any effect on fruit color, SSC, and SDP at harvest. Fruit from trees with an OA branch configuration system had higher firmness and lower watercore than those from trees with a TS or TA training. Leaves from trees receiving a TA branch configuration had greater leaf area, fresh weight, and $\mathrm{K}$ and $\mathrm{Mn}$ concentrations than those with other trainings. Based on this long-term study, training trees into a TA configuration rather than an OA system is recommended if the management and operation of apple production mandate the use of a single row "upright wall" structure to facilitate mechanical harvesting.

\section{Acknowledgements}

We thank the Idaho Apple Commission and the Idaho Agricultural Experiment Station for their financial support of this project. This work was supported in part by U.S. Department of Agriculture National Institute of Food and Agriculture Specialty Crop Research Initiative project "AppleRoot2Fruit: Accelerating the development, evaluation and adoption of new apple rootstocks" (2016-51181-25406). We are also thankful to the C \& O Nursery in Washington State for providing the experimental trees. Guidance provided by Professor Terence Robinson of Cornell University and Dr. Gennaro Fazio of USDA-ARS in this project is gratefully appreciated.

\section{References}

Agusti, M., Andreu, I., Juan, M., Almela, V., \& Zacarias, L. (1998). Effects of ringing branches on fruit size and maturity of peach and nectarine cultivars. Journal of Horticultural Science \& Biotechnology, 73, 537-540. https://doi.org/10.1080/14620316.1998.11511011

Allen, R. G., Pereira, L. S., Raes, D., \& Smith, M. (1998). Crop evapotranspiration. Guidelines for computing crop water requirements. FAO Irrigation and Drainage (p. 56). FAO, Rome, Italy.

Autio, W. R., Hayden, R. A., Micke, W. C., \& Brown, G. R. (1996). Rootstock affects ripening, color, and shape of 'Starkspur Supreme Delicious' apples in the 1984 NC-140 cooperative plant-ing. Fruit Variety Journal, $50,45-53$.

Bartram, R. D., Bramlage, W., Kupferman, E. M., Olsen, K. L., Patterson, M. E., \& Thompson, J. (1993). Apple maturity program handbook. USDA-ARS Tree Fruit.

Chaplin, M. H., \& Dixon, A. R. (1974). A method for analysis of plant tissue by direct reading spark emission 
spectroscopy. Applied Spectroscopy, 28, 5-8. https://doi.org/10.1366/000370274774332894

Chun, I. J., Fallahi, E., Colt, W. M., Shafii, B., \& Tripepi, R. R. (2001). Effects of rootstocks and microsprinkler fertigation on mineral concentrations, yield, and fruit color of 'BC-2 Fuji' apple. Journal of American Pomology Society, 55,197-205.

Clements, J. (2011). 'Mini’ Apple Orchard Systems Trial: A Comparison of central-leader, vertical-axis, and tall-spindle apple orchard systems on three different rootstocks. Fruit Notes, 76, 10-13.

Dallabetta, N., Costa, F., Pasqualini, J., Noferini, M., \& Costa G., (2014). The influence of training system on apple fruit quality. Acta Horticulturae, 1058, 55-62. https://doi.org/10.17660/ActaHortic.2014.1058.4

Davie, S. J., Stassen, P. J. C., Van der Walt, M., \& Snijder, B. (1995). Girdling avocado trees for improved production. South African Avocado Growers' Association Yearbook, 18 (pp. 51-53).

Day, K. R., \& DeJong, T. M. (1990). Girdling of early season 'Mayfire' nectarine trees. Journal of Horticultural Science, 65, 529-534. https://doi.org/10.1080/00221589.1990.11516089

Fallahi, E., \& Simons, B. (1993). Influence of Fruit Spacing on Fruit Quality and Mineral Partitioning of 'Redchief Delicious' Apple Under Full Crop Conditions. Fruit Varieties Journal, 47(3), 172-178.

Fallahi, E., Arzani, K., \& Fallahi, B. (2013). Long-term leaf mineral nutrition in 'Pacific Gala' apple (Malus domestica Borkh.) as affected by rootstock type and irrigation system during six stages of tree development. Journal of Horticultural Science and Biotechnology, 88(6), 685-692. https://doi.org/10.1080/14620316. 2013.11513025

Fallahi, E., Chun, I. J., Neilsen, G. H., \& Colt, W. M. (2001). Effects of three rootstocks on photo-synthesis, leaf mineral nutrition, and vegetative growth of 'BC-2 Fuji' apple trees. Journal of Plant Nutrition, 24, 827-834. https://doi.org/10.1081/PLN-100103776

Fallahi, E., Colt, W. M., \& Fallahi, B. (2001). Optimum ranges of leaf nitrogen for yield, fruit quality, and photosynthesis in 'BC-2 Fuji' apple. Journal of American Pomology Society, 55, 68-75.

Fallahi, E., Fallahi, B., \& Shafii, B. (2013). Irrigation and rootstock influence on water use, tree growth, yield, and fruit quality at harvest at different ages of trees in 'Pacific Gala' apple. HortScience, 48(5), 588-593. https://doi.org/10.21273/HORTSCI.48.5.588

Fallahi, E., Fallahi, B., Kiester, J., \& Mahdavi, S. (2018). Cambium disconnection, rootstock, and canopy training impacts on growth and leaf mineral nutrients in 'Aztec Fuji' apple. International Journal of Fruit Science, 19(3), 231-245. https://doi.org/10.1080/15538362.2018.1559119

Fallahi, E., Fallahi, B., Shafii, B., \& Morales, B. (2007). Water use, tree growth, and leaf mineral nutrients of young 'Fuji' apples as influenced by different irrigation systems. Acta Horticulturae, 721, 63-70. https://doi.org/10.17660/ActaHortic.2006.721.7

Fallahi, E., Kiester, M. J., Fallahi, B., \& Mahdavi, S. (2018). Rootstock, Canopy Architecture, Bark Girdling, and Scoring Influence on Growth, Productivity, and Fruit Quality at Harvest in 'Aztec Fuji' Apple. Hortscience, 53(11), 1629-1633. https://doi.org/10.21273/HORTSCI13348-18

Fallahi, E., Mahdavi, S., Kaiser, C., \& Fallahi, B., (2019). Phytopigments, proline, chlorophyll index, yield and leaf nitrogen as impacted by rootstock, training sysyem, and girdling in 'Aztec Fuji' apple. American Journal of Plant Sciences, 10, 1583-1598. https://doi.org/10.4236/ajps.2019.109112

Fallahi, E., Ratnaprabha, R., Tripepi, R., Shafii, B., \& Fallahi, B. (2007). Tree growth, yield, fruit quality, and mineral partitioning as affected by rootstock and irrigation methods. International Journal of Fruit Science, 7, 3-24. https://doi.org/10.1300/J492v07n01_02

Fallahi, E., Tehranifar, A., \& Gharaghani, A. (2017). Cluster Management to Improve Berry Quality in Young 'Alborz' Table Grape in the Intermountain West Region, USA. International Journal of Fruit Science, 17(4), 349-357. https://doi.org/10.1080/15538362.2017.1315629

Fernandez-Escobar, R., Martin, R., Lopez-Rivares, P., \& Paz Suarez, M. (1987). Girdling as a means of increasing fruit size and earliness in peach and nectarine cultivars. Journal of Horticultural Science, 62, 463-468. https://doi.org/10.1080/14620316.1987.11515807

Gandev, S., Nanev, I., Savov, P. R., Isuf, E., Kornov, G., \& Serbezova, D. (2016). The effect of three training systems on the vegetative and reproductive habits of the apple cultivar 'Braeburn' grafted on M9 rootstocks. Bulgarian Journal of Agricultural Science, 22(4), 600-603. 
Goodwin, I. (2016). Cordon tree training systems on Open Tatura trellis. Retrieved from https://www.youtube. com/watch? $v=1 \mathrm{jt} 34 \mathrm{VrkfEg}$

Hampson, C. R., Harvey, A., Quamme, R., \& Brownlee, T. (2002). Canopy Growth, Yield, and Fruit Quality of 'Royal Gala' Apple Trees Grown for Eight Years in Five Tree Training Systems. HortScience, 37(4). https://doi.org/10.21273/HORTSCI.37.4.627

He, L., \& Schupp, J. (2018). Sensing and automation in pruning of apple trees: A review. Agronomy, 8, 211. https://doi.org/10.3390/ agronomy8100211

Hoying, S. A. (2012). Experiences with support systems for the Tall Spindle apple planting system. New York Fruit Quarterly, 20(4), 3-8.

Kappel, F., \& Quamme, H. A. (1993). Orchard training systems influence early canopy development and light microclimate within apple tree canopies. Canadian Journal of Plant Science, 73, 237-248. https://doi.org/ 10.4141 /cjps $93-038$

Mills, H. A., \& Jones, J. B. Jr. (1996). Plant Analysis Handbook II. MicroMacro Publishing, Inc. Athens, GA.

Ozkan, Y., Yildiz, K., Kucuker, E., Cekic, C., Ozgen, M., \& Akca, Y., (2012). Early performance of cv. Jonagold apple on M.9 in five tree training systems. Horticultural Science, 4, 158-163. https://doi.org/10.17221/ 35/2012-HORTSCI

Proebsting, E. (1994). Strategy development for managing drought (pp. 39-50). In K. M. Williams \& T. W. Ley (Eds.), Tree fruit irrigation. Good Fruit Grower, Yakima, Washington.

Raffo, M. D., Calvo, P., De Angelis, V., Mañueco, L., Ziaurriz, S., \& Menni, F. (2011). Effects of trunk girdling, on fruit productions, fruit size, and tree vigor on 'Bartlett' pears in Rio Negro and Neuquén Valley, Argentina. Acta Horticulturae, 909, 645-650. https://doi.org/10.17660/ActaHortic.2011.909.78

Reynolds, A. G., \& de Savigny, C. (2004). Influence of girdling and gibberellic acid on yield components, fruit composition, and vestigial seed formation of 'Sovereign Coronation' table grapes. HortScience, 39(3), https://doi.org/10.21273/HORTSCI.39.3.541

Robinson, T. L., Hoying, S. A., \& Reginato, G. H. (2006). The tall spindle apple production system. New York Fruit Quarterly, 14(2), 21-28.

Schechter, I., Proctor, J. T. A., \& Elfving, D. C. (1994). Apple fruit removal and limb girdling affect fruit and leaf characteristics. Journal of American Society of Horticultural Science, 119(2), 157-162. https://doi.org/ 10.21273/JASHS.119.2.157

Washington State University. (2020). Washington State University Tree Fruit Research and Extension Center. Retrieved January 10, 2020, from http://www.tfrec.wsu.edu

Wertheim, S. J., de Jager, A., \& Duyzens, M. J. J. P. (1986). Comparison of single-row and multi-row planting systems with apple, with regard to productivity, fruit size and colour and light conditions. Acta Horticulturae, 160, 243-258. https://doi.org/10.17660/ActaHortic.1986.160.25

Westwood, M. N. (1978). Temperate Zone Pomology. W.H. Freeman and Company. San Francisco, CA.

Westwood, M. N., \& Roberts, A. N. (1970). The Relationship Between Trunk-Cross-Sectional Area of Apple Trees. Hortscience, 95(1), 28-30.

\section{Copyrights}

Copyright for this article is retained by the author(s), with first publication rights granted to the journal.

This is an open-access article distributed under the terms and conditions of the Creative Commons Attribution license (http://creativecommons.org/licenses/by/4.0/). 